\title{
Electrochemical Oxidation of
} Resorcinol in Aqueous Medium Using Boron-Doped Diamond Anode: Reaction Kinetics and Process Optimization with Response Surface Methodology

\author{
Bahadır K. Körbahti* and Pelin Demirbüken \\ Faculty of Engineering, Chemical Engineering Department, Mersin University, Mersin, Turkey
}

Electrochemical oxidation of resorcinol in aqueous medium using boron-doped diamond anode (BDD) was investigated in a batch electrochemical reactor in the presence of $\mathrm{Na}_{2} \mathrm{SO}_{4}$ supporting electrolyte. The effect of process parameters such as resorcinol concentration (100-500 g/L), current density (2-10 mA/cm²), Na $\mathrm{SO}_{4}$ concentration

OPEN ACCESS

Edited by:

Nasr Bensalah,

Qatar University, Qatar

Reviewed by:

Mohamed Faouzi Ahmadi,

Al Baha University, Saudi Arabia

Amirhossein Mehrkesh,

YTC America Inc., United States

${ }^{*}$ Correspondence:

Bahadir K. Körbahti

korbahti@mersin.edu.tr

Specialty section:

This article was submitted to Green and Environmental Chemistry,

a section of the journal

Frontiers in Chemistry

Received: 03 February 2017

Accepted: 25 September 2017

Published: 13 October 2017

Citation:

Körbahti BK and Demirbüken P (2017)

Electrochemical Oxidation of

Resorcinol in Aqueous Medium Using Boron-Doped Diamond Anode:

Reaction Kinetics and Process

Optimization with Response Surface Methodology. Front. Chem. 5:75. doi: 10.3389/fchem.2017.00075
$(0-20 \mathrm{~g} / \mathrm{L})$, and reaction temperature $\left(25-45^{\circ} \mathrm{C}\right)$ was analyzed on electrochemical oxidation using response surface methodology (RSM). The optimum operating conditions were determined as $300 \mathrm{mg} / \mathrm{L}$ resorcinol concentration, $8 \mathrm{~mA} / \mathrm{cm}^{2}$ current density, $12 \mathrm{~g} / \mathrm{L} \mathrm{Na} \mathrm{SO}_{4}$ concentration, and $34^{\circ} \mathrm{C}$ reaction temperature. One hundred percent of resorcinol removal and $89 \%$ COD removal were obtained in 120 min reaction time at response surface optimized conditions. These results confirmed that the electrochemical mineralization of resorcinol was successfully accomplished using BDD anode depending on the process conditions, however the formation of intermediates and by-products were further oxidized at much lower rate. The reaction kinetics were evaluated at optimum conditions and the reaction order of electrochemical oxidation of resorcinol in aqueous medium using BDD anode was determined as 1 based on COD concentration with the activation energy of $5.32 \mathrm{~kJ} / \mathrm{mol}$ that was supported a diffusion-controlled reaction.

Keywords: boron-doped diamond, electrochemical oxidation, optimization, reaction kinetics, resorcinol, response surface methodology, wastewater treatment

Abbreviations: A, frequency factor $\left(\mathrm{min}^{-1}\right)$; $\mathrm{A}_{\mathrm{e}}$, electrode area $\left(\mathrm{m}^{2}\right)$; ANOVA, analysis of variance; BDD, boron-doped diamond; $\mathrm{C}_{0}$, initial resorcinol concentration $(\mathrm{mg} / \mathrm{L})$; CCD, central composite design; COD, chemical oxygen demand $(\mathrm{mg} / \mathrm{L}) ; \mathrm{COD}_{\mathrm{o}}$, initial chemical oxygen demand at $t=0(\mathrm{mg} / \mathrm{L}) ; \mathrm{COD}_{\mathrm{f}}$, final chemical oxygen demand at $t=120 \mathrm{~min}(\mathrm{mg} / \mathrm{L})$; $\mathrm{COD}_{\mathrm{r}}$, COD removed; $\mathrm{E}_{\mathrm{a}}$, activation energy (kJ/mol); EC, energy consumption $\left(\mathrm{kWh} / \mathrm{kg} \mathrm{COD}_{\mathrm{r}}\right)$; F, Faraday constant $(96,485$ $\mathrm{C} / \mathrm{mol}) ; \mathrm{J}$, current density $\left(\mathrm{mA} / \mathrm{cm}^{2}\right) ; \mathrm{J}_{\text {lim }}^{\mathrm{o}}$, initial limiting current density $\left(\mathrm{mA} / \mathrm{cm}^{2}\right) ; \mathrm{k}$, number of process parameters (factors) in Equation (5); $\mathrm{k}$, reaction rate constant $\left(\mathrm{min}^{-1}\right)$ in Equations (14-17); $\mathrm{k}$, mass transfer coefficient ( $\left.\mathrm{m} / \mathrm{s}\right)$; $\mathrm{n}$, reaction order; RSM, response surface methodology; $\mathrm{t}$, reaction time $(\mathrm{min}) ; \mathrm{T}$, reaction temperature $\left({ }^{\circ} \mathrm{C}\right) ; \mathrm{V}_{\mathrm{m}}$, mean cell voltage $(\mathrm{Volt})$; $\mathrm{V}_{\mathrm{R}}$, reaction volume $(\mathrm{mL}) ; x_{\mathrm{i}}, x_{\mathrm{j}}$, process parameters (factors); $x_{S B E R}$, fractional COD conversion in stirred batch electrochemical reactor; $y$, predicted value of the model (response); Greek Letters; $\alpha$, parameter determines the location of the points in experimental design in Table 1; $\alpha, \mathrm{J} / \mathrm{J}_{\mathrm{lim}}^{\mathrm{o}}$ ratio in Equation (12); $\beta_{\mathrm{o}}, \beta_{\mathrm{i}}, \beta_{\mathrm{ii}}, \beta_{\mathrm{ij}}$, constant, linear, quadratic, and interaction coefficients in the model; $\Delta \mathrm{t}$, reaction time (min). 


\section{INTRODUCTION}

Resorcinol (1,3-dihydroxybenzene, $\mathrm{C}_{6} \mathrm{H}_{6} \mathrm{O}_{2}$, CAS No. 108-46-3) is a white crystalline phenolic compound and it is a main component of the adhesives in rubber products and wood additives. The other uses include the manufacture of specialty chemicals, explosive primers, antioxidants, flame retardants, UV stabilizers, dyes, agricultural chemicals, fungicidal creams and lotions, meta-amino phenols, hair dyes, and pharmaceuticals (Hahn et al., 2006). Resorcinol can be released into the environment as hazardous pollutant from industrial production, coal conversion processes, oil shale mining refineries, and consumer uses such as hair dyes and pharmaceuticals. Although in low tonnage, resorcinol is most common in hair dyes, shampoos, hair lotions, peels, and in products used to treat acne, eczema, and other dermatological issues (Hahn et al., 2006). Therefore, resorcinol can be released into the environment during the production and processing of industrial facilities and from domestic effluents as well. The exposure to resorcinol causes toxicological effects in humans and animals which were reported as thyroid dysfunction, skin irritation, central nervous system disturbances, red blood cell changes, and decreases in body weight gain and decreased survival (Hahn et al., 2006).

The scientific studies demonstrate that resorcinol has both in vivo and in vitro antithyroid activity (Lynch et al., 2002). Resorcinol inhibits the activity of thyroid peroxidase enzymes responsible for the incorporation of iodine into tyrosine residues during the synthesis of thyroid hormone. Clinical case reports documented that continuous exposure to high doses of resorcinol with large amounts of resorcinol containing ointments over a long period of time for months to years may induce reversible hypothyroidism (Lynch et al., 2002). It was reported that thyroid effects may occur as a result of dermal exposure to integritycompromised skin at resorcinol dose levels in the range 34$122 \mathrm{mg} / \mathrm{kg} /$ day based on the human data (Lynch et al., 2002).

The subchronic toxicity of resorcinol was evaluated in 17-day and 13-week studies in F344 rats and in $\mathrm{B} 6 \mathrm{C} 3 \mathrm{~F} 1$ mice to establish the dose ranges for a 2-year carcinogenicity study (National Toxicology Program, 1992). National Toxicology Program (1992) reported that resorcinol at high doses to rodents can disrupt thyroid hormone synthesis and can produce goitrogenic effects. These effects were not seen in a 2-year bioassay at doses of up to $520 \mathrm{mg} / \mathrm{kg} /$ day (National Toxicology Program, 1992). Skowroñ and Zapór (2004) investigated the cytotoxicity in 3T3 fibroblast cells in short-term ( $3 \mathrm{~h}$ ) and long-term (72 h, 6 weeks) exposure

TABLE 1 | Experimental design for the electrochemical oxidation of resorcinol in aqueous medium using BDD anode.

\begin{tabular}{|c|c|c|c|c|c|c|}
\hline \multicolumn{2}{|c|}{ Process parameters } & \multicolumn{5}{|c|}{ Coded $\alpha$ levels } \\
\hline & & -2 & -1 & 0 & +1 & +2 \\
\hline$x_{1}$ & Resorcinol concentration (mg/L) & 100 & 200 & 300 & 400 & 500 \\
\hline$x_{2}$ & Current density $\left(\mathrm{mA} / \mathrm{cm}^{2}\right)$ & 2 & 4 & 6 & 8 & 10 \\
\hline$x_{3}$ & $\mathrm{Na}_{2} \mathrm{SO}_{4}$ concentration $(\mathrm{g} / \mathrm{L})$ & 0 & 5 & 10 & 15 & 20 \\
\hline$x_{4}$ & Reaction temperature $\left({ }^{\circ} \mathrm{C}\right)$ & 25 & 30 & 35 & 40 & 45 \\
\hline
\end{tabular}

to resorcinol in the bioreactor. The authors reported that after $3 \mathrm{~h}$ of exposure the resorcinol caused inhibition of mitochondrial activity in concentrations of $2,500-4,000 \mu \mathrm{g} / \mathrm{cm}^{3}$ and inhibition of the intake of neutral red dye by lysosomes in concentrations of 1,500-4,000 $\mu \mathrm{g} / \mathrm{cm}^{3}$ (Skowroñ and Zapór, 2004). Resorcinol in concentrations above $1 \mu \mathrm{g} / \mathrm{cm}^{3}$ caused inhibition of $3 \mathrm{~T} 3$ fibroblast cell growth in the mitochondrial function and total cell protein tests after $72 \mathrm{~h}$ of exposure (Skowroñ and Zapór, 2004).

The environmental exposures of the general human population to resorcinol may be the result of drinking water consumption and through air inhalation. Resorcinol may be present in ground water at trace to low levels especially in areas where aquifers flow through rocks that are rich in organic material (Lynch et al., 2002). However, there is a lack of information in the literature from which source to quantify the environmental exposures of the general human population to resorcinol through drinking water and the inhalation of ambient air (Lynch et al., 2002).

In the literature, several biological, physical, chemical, physicochemical, and advanced oxidation processes have been investigated for the abatement of phenolic compounds in wastewater due to their hazardous and toxicological effects (Zareie et al., 2001; Körbahti et al., 2002; Cañizares et al., 2005b, 2006; Nasr et al., 2005; Duan et al., 2013; Li et al., 2013). Electrochemical processes are the most promising technology that offers competitive advantages, effective oxidation performance and environmental compatibility in treatment of bio-refractory, toxic, and highly concentrated organic wastewater (Cañizares et al., 2005b; Comninellis and Chen, 2010; Sirés and Brillas, 2012; Duan et al., 2013; Li et al., 2013; Körbahti and Taşyürek, 2015; Jarrah and Mu'azu, 2016; Mu’azu et al., 2016).

In electrochemical processes, organic pollutants in aqueous medium can be removed by direct and indirect mechanisms depending on the properties of the anodes and process conditions (Comninellis and Chen, 2010; Jin et al., 2014). Direct oxidation occurs at the anode surface and indirect oxidation occurs in the aqueous medium by the production of redox reagents (Panizza and Cerisola, 2009; Comninellis and Chen, 2010; Brillas and Martínez-Huitle, 2015).

Boron-doped diamond (BDD) thin film is a new electrode material superior to $\mathrm{TiO}_{2}, \mathrm{Pt}, \mathrm{PbO}_{2}, \mathrm{IrO}_{2}, \mathrm{SnO}_{2}$, and glassy carbon anodes due to its corrosion resistance, good conductivity, inert surface, mechanical and chemical stability, and increased mineralization rates at high current efficiencies (Chen et al., 2004; Nasr et al., 2005; Panizza and Cerisola, 2007; Comninellis et al., 2008; Weiss et al., 2008; Liu et al., 2009). Diamond films are not conductive, therefore doping with boron atoms make the diamond films electrical conducting. BDD thin films usually prepared on silicon, niobium, titanium, tungsten, molybdenum, tantalum, or glassy carbon materials by chemical vapor deposition (CVD) and the doping level of boron in the diamond layer can be expressed as $\mathrm{B} / \mathrm{C}$ ratio which is about 1,000-10,000 ppm (Panizza and Cerisola, 2009).

In the literature, $\mathrm{BDD}$ anodes were investigated in electrochemical oxidation of organic pollutants such as carboxylic acids, pesticides, cyanides, pharmaceuticals, chlorobenzene, phenols and phenol derivatives, surfactants, 
textile dyes, and real wastewaters (Liu et al., 2009; Panizza and Cerisola, 2009; Sirés and Brillas, 2012; Brillas and MartínezHuitle, 2015). During the electrolysis physisorbed hydroxyl radicals produce at $\mathrm{BDD}$ anodes by the oxidation of water molecules. Hydroxyl radicals assist the nonselective oxidation of organic compounds ( $\mathrm{R}$ ) and their reaction intermediates into $\mathrm{CO}_{2}$ and $\mathrm{H}_{2} \mathrm{O}$ which may result in complete mineralization (Panizza and Cerisola, 2009; Comninellis and Chen, 2010).

$$
\begin{aligned}
& B D D+\mathrm{H}_{2} \mathrm{O} \rightarrow \mathrm{BDD}\left({ }^{\bullet} \mathrm{OH}\right)+\mathrm{H}^{+}+e^{-} \\
& B D D(\bullet \mathrm{OH})+\mathrm{R} \rightarrow \mathrm{BDD}+\mathrm{CO}_{2}+\mathrm{H}_{2} \mathrm{O}
\end{aligned}
$$

Besides hydroxyl radicals produced by water oxidation, it is known that peroxodisulfate $\left(\mathrm{S}_{2} \mathrm{O}_{8}^{2-}\right)$ oxidant also generates in sulfate medium at BDD anodes (Serrano et al., 2002; Cañizares et al., 2005a; Li et al., 2010; Sirés and Brillas, 2012; Davis et al., 2014). Once, $\mathrm{Na}_{2} \mathrm{SO}_{4}$ dissolves in the aqueous medium it ionizes into $\mathrm{Na}^{+}$and $\mathrm{SO}_{4}^{2-}$. Then peroxodisulfate $\left(\mathrm{S}_{2} \mathrm{O}_{8}^{2-}\right)$ produces at high overpotential supplied by the BDD anode in the presence of $\mathrm{SO}_{4}^{2-}$ ions in the electrolyte.

$$
\begin{aligned}
& \mathrm{Na}_{2} \mathrm{SO}_{4} \rightarrow 2 \mathrm{Na}^{+}+\mathrm{SO}_{4}^{2-} \\
& 2 \mathrm{SO}_{4}^{2-} \rightarrow \mathrm{S}_{2} \mathrm{O}_{8}^{2-}+2 e^{-}
\end{aligned}
$$

The aim of this study was to investigate the electrochemical oxidation of resorcinol in aqueous medium using boron-doped diamond (BDD) anode in the presence of $\mathrm{Na}_{2} \mathrm{SO}_{4}$ supporting electrolyte. The effect of process parameters on COD removal, mass transfer coefficient $\left(\mathrm{k}_{\mathrm{m}}\right), \mathrm{J} / \mathrm{J}_{\lim }^{\circ}$ values $(\alpha)$, and energy consumption was determined. The process optimization was accomplished using response surface methodology (RSM) and the reaction kinetics of electrochemical oxidation of resorcinol in aqueous medium using BDD anode were evaluated at response surface optimized conditions.

\section{MATERIALS AND METHODS}

\section{Chemicals and Materials}

Resorcinol (Merck), $\mathrm{Na}_{2} \mathrm{SO}_{4}$ (Riedel-de Haën), $\mathrm{HgSO}_{4}$ (Merck), methanol (Merck), and Merck Spectroquant ${ }^{\circledR} 14541$ COD cell tests were purchased in extra pure grade and used without purification. Double distilled water was produced using water still (GFL-2008) and ultrapure water system (Millipore Simplicity ${ }^{\circledR}$ $\mathrm{UV})$ with the resistivity of $18.2 \mathrm{M} \Omega . \mathrm{cm} @ 25^{\circ} \mathrm{C}$, TOC $<5 \mathrm{ppb}$.

\section{Experimental Set-Up and Procedure}

DURAN $^{\circledR}$ batch electrochemical reactor (Rettberg, Germany) with heating/cooling jacket used in this study. The net reaction volume was $600 \mathrm{~mL}$. Three plates DIACHEM ${ }^{\circledR}$ borondoped diamond (Nb/BDD) anode (CONDIAS, Germany) and 4 cylindrical $(\phi=12.0 \mathrm{~mm})$ iron cathode were used as electrodes with $15 \mathrm{~mm}$ anode/cathode spacing. Iron electrodes were purchased from local sources. Total electrode surface area was $280 \mathrm{~cm}^{2}$. Batch electrochemical reactor was equipped with programmable Goodwill PST-3201 power supply, Heidolph RZR 2021 mechanical mixer, thermometer, Memmert WB 22 heating/cooling water bath and Heidolph PD 5206 peristaltic pump. Reaction medium was mixed at $750 \mathrm{rpm}$. Samples were withdrawn from the electrochemical reactor at regular periods for the analytical measurements.

\section{Analytical Measurements}

HPLC analysis of resorcinol were conducted using Inertsil ODS$3(5 \mu \mathrm{m}, 4.6 \times 250 \mathrm{~mm})$ column in a Shimadzu Prominence LC-20AD Liquid Chromatography equipped with DGU-20A5 degasser, CBM-20Alite System Controller, LC-20AD gradient pump, SIL-20A auto sampler, CTO-20A column oven, and SPD20A UV/Vis detector. Mobile phase consisted of methanol and water $(75 / 25)$ at a flow rate of $1.0 \mathrm{~mL} / \mathrm{min}$. UV detection was performed at $270 \mathrm{~nm}$ wavelength. The column temperature and injection volume were set as $40^{\circ} \mathrm{C}$ and $30 \mu \mathrm{L}$, respectively. The regression coefficient of the calibration curve for resorcinol was $R^{2}=0.9991$. $\mathrm{pH}$ was measured using WTW inoLab BNC720 model $\mathrm{pH}$ meter/conductivity meter. Merck Spectroquant ${ }^{\circledR}$ 14541 COD cell tests and Nova 60 water/wastewater photometer were used for the COD analysis.

\section{Design of Experiments and Process Optimization Using Response Surface Methodology}

Response surface methodology (RSM) is a mathematical and statistical method used in designing experiments, building models, evaluating the effect of process variables, and searching optimum operating conditions for the responses (Montgomery, 2009; Myers et al., 2009). The responses can be related to the factors by linear or quadratic models in RSM. The quadratic model, which also includes the linear model, is given in Equation (5) (Montgomery, 2009; Myers et al., 2009):

$$
y=\beta_{o}+\sum_{i=1}^{k} \beta_{i} x_{i}+\sum_{i=1}^{k} \beta_{i i} x_{i}^{2}+\sum_{i} \sum_{<j=2}^{k} \beta_{i j} x_{i} x_{j}
$$

RSM is a very powerful tool that provides detailed mathematical and statistical analysis of the experimental results. In the literature, RSM was applied for the experimental design and process optimization in electrochemical oxidation of various types of wastewater containing textile dyes, pharmaceuticals, paint, dairy effluents, pulp and paper, phenols, phenol derivatives, landfill leachate, organic acids, and pesticides in most common using Box-Behnken design (BBD) and central composite design (CCD) (Nair et al., 2014). In this study, RSM was utilized using central composite design (CCD) for the electrochemical oxidation of resorcinol in aqueous medium at BDD anode. Central composite design (CCD) is the most popular class of second-order designs that provides very good predictions in the middle of the design space. CCD with four parameters at five levels was coded between the ranges of -2 and +2 using Design-Expert $\left.{ }^{(}\right) 10$ as presented in Table 1. The runs were augmented in one block with 16 factorial, 8 axial, 6 center, and additional 8 axial points for the design space and carried out in randomized order in order to estimate pure error for the lack of fit test as shown in Table 2. The process variables (factors) were resorcinol concentration (100-500 mg/L), current 
density $\left(2-10 \mathrm{~mA} / \mathrm{cm}^{2}\right), \mathrm{Na}_{2} \mathrm{SO}_{4}$ electrolyte concentration $(0-20 \mathrm{~g} / \mathrm{L})$, and reaction temperature $\left(25-45^{\circ} \mathrm{C}\right)$; and the responses were chemical oxygen demand (COD) removal, mass transfer coefficient $\left(\mathrm{k}_{\mathrm{m}}\right), \mathrm{J} / \mathrm{J}_{\lim }^{\circ}$ values $(\alpha)$, and energy consumption.

\section{RESULTS AND DISCUSSION Effect of Process Parameters}

The effect of resorcinol concentration, current density, $\mathrm{Na}_{2} \mathrm{SO}_{4}$ electrolyte concentration and reaction temperature were investigated on electrochemical oxidation of resorcinol in aqueous medium using BDD anode in a batch electrochemical reactor. Mean cell voltage, initial and final COD values during the electrochemical treatment can be seen in Table 2. In the study, calculations were made by using the experimental results in Table 2 and analyzed for the process optimization using RSM. COD removal, mass transfer coefficient $\left(\mathrm{k}_{\mathrm{m}}\right), \mathrm{J} / \mathrm{J}_{\text {lim }}^{\circ}$ values $(\alpha)$, and energy consumption data were processed for Equation (5) including ANOVA in order to obtain the interaction between the process variables and the responses. The quadratic response surface models were obtained for the responses in Equations (6-9) and the statistical significance verified by the analysis of variance (ANOVA) in Table 3. In Equations (6-9), $y_{\mathrm{COD}}$, $y_{\mathrm{km}}, y_{\alpha}$, and $y_{\mathrm{EC}}$ are COD removal, mass transfer coefficient, $\mathrm{J} / \mathrm{J}_{\lim }^{\circ}$ values, and energy consumption, respectively; and $x_{1}$, $x_{2}, x_{3}$, and $x_{4}$ are process variables (factors) of resorcinol concentration $(\mathrm{mg} / \mathrm{L})$, current density $\left(\mathrm{mA} / \mathrm{cm}^{2}\right), \mathrm{Na}_{2} \mathrm{SO}_{4}$ electrolyte concentration $(\mathrm{g} / \mathrm{L})$, and reaction temperature $\left({ }^{\circ} \mathrm{C}\right)$, respectively. the design. The ideal VIF value is 1.00 and if the design has multilinear constraints multicollinearity exists to a greater degree with VIF $>10$. The VIF values were obtained as 1.00 and 1.01 for COD removal, $\mathrm{k}_{\mathrm{m}}, \mathrm{J} / \mathrm{J}_{\mathrm{lim}}^{\circ}$ values and energy consumption indicating that there was no multicollinearity and the coefficients were very well estimated.

$F$-value is the test for comparing the sources mean square to the residual mean square and $p$-value is the probability of seeing the observed $F$-value for factor effects. Model $F$-values of 2.44, $3.08,2.35$, and 10.30 imply the quadratic models are significant for COD removal, $\mathrm{k}_{\mathrm{m}}, \mathrm{J} / \mathrm{J}_{\mathrm{lim}}^{\circ}$ values and energy consumption, respectively. $P$-values less than 0.05 indicate the model terms are significant and signal/noise $(\mathrm{s} / \mathrm{n})$ ratio $>4$ is desirable for adequate precision. Significant model terms have a real effect on the response and lack of fit. $S / n$ ratios of $6.775,5.870,7.952$, and 12.951 imply adequate signals and $P<0.05$ indicate the significance for the quadratic models that encompasses $95 \%$ confidence interval for the design space. In Table 3, the lack of fit $F$-values of 0.95 and 1.39 indicate the insignificance for COD removal and mass transfer coefficient; and $F$-values of 92.01 and 13.40 indicate the significance for $\mathrm{J} / \mathrm{J}_{\lim }^{\circ}$ values and energy consumption. In this study, residual plots followed a normal distribution, studentized residuals and outlier-t plots indicated good approximations for the fitted quadratic models to the response surfaces (diagnostic plots were not shown).

Figures 1A-C show the effect of process parameters on COD removal in $3 \mathrm{D}$ surface and $2 \mathrm{D}$ contour plots. COD removal was obtained between 10.6 and $90.3 \%$ with standard deviation of $15.5 \%$. Operating region for higher than $85 \%$ COD removal was determined at 9.1-14.8 $\mathrm{g} / \mathrm{L} \mathrm{Na}_{2} \mathrm{SO}_{4}, 6.8-9.9 \mathrm{~mA} / \mathrm{cm}^{2}$ current density and $26-34^{\circ} \mathrm{C}$ reaction temperature in Figures 1A-C.

$$
\begin{aligned}
y_{\mathrm{COD}}= & 0.010955 x_{1}+10.55437 x_{2}+10.92951 x_{3}+3.72522 x_{4}+8.46875 \times 10^{-3} x_{1} x_{2} \\
& -1.48750 \times 10^{-3} x_{1} x_{3}-4.46250 \times 10^{-3} x_{1} x_{4}-0.036875 x_{2} x_{3}+0.034375 x_{2} x_{4} \\
& -0.082750 x_{3} x_{4}+1.60235 \times 10^{-4} x_{1}^{2}-0.84059 x_{2}^{2}-0.29579 x_{3}^{2}-0.024965 x_{4}^{2}-87.73641 \\
y_{\mathrm{k}_{\mathrm{m}}\left(\times 10^{6}\right)}= & 0.015553 x_{1}+1.45125 x_{2}+1.26430 x_{3}+1.25892 x_{4}+6.66641 \times 10^{-4} x_{1} x_{2}-2.14507 \times 10^{-4} x_{1} x_{3} \\
& -5.04257 \times 10^{-4} x_{1} x_{4}-2.57349 \times 10^{-3} x_{2} x_{3}+5.20183 \times 10^{-3} x_{2} x_{4}-0.015768 x_{3} x_{4} \\
& -1.37062 \times 10^{-6} x_{1}^{2}-0.11317 x_{2}^{2}-0.026007 x_{3}^{2}-0.013908 x_{4}^{2}-31.21950 \\
y_{\alpha}= & -4.82555 \times 10^{-3} x_{1}+1.15881 x_{2}-2.00075 x_{3}+0.68115 x_{4}-6.99771 \times 10^{-4} x_{1} x_{2}+9.13947 \\
& \times 10^{-5} x_{1} x_{3}+2.71615 \times 10^{-4} x_{1} x_{4}+1.01179 \times 10^{-3} x_{2} x_{3}-4.05986 \times 10^{-3} x_{2} x_{4} \\
& -1.19447 \times 10^{-5} x_{1}^{2}-0.056538 x_{2}^{2}+0.081820 x_{3}^{2}-0.010587 x_{4}^{2}-1.17525 \\
y_{\mathrm{EC}}= & -1.25669 x_{1}+38.36969 x_{2}+0.45101 x_{3}-22.70344 x_{4}-0.065281 x_{1} x_{2}+0.013980 x_{1} x_{3} \\
& +7.91250 \times 10^{-3} x_{1} x_{4}-1.75525 x_{2} x_{3}-0.32888 x_{2} x_{4}+0.10520 x_{3} x_{4}+1.50082 \times 10^{-3} x_{1}^{2}+2.90536 x_{2}^{2} \\
& -0.10089 x_{3}^{2}+0.28896 x_{4}^{2}+571.36412
\end{aligned}
$$

Process variables $x_{1}, x_{2}, x_{3}$, and $x_{4}$ were evaluated for design matrix using Design-Expert ${ }^{\odot} 10$ and no aliases were found for the response surface quadratic models. The lack of fit test is valid for this study according to degrees of freedom (df) values where minimum $3 \mathrm{df}$ for lack of fit and $4 \mathrm{df}$ for pure error is recommended for a valid lack of fit test. The variance inflation factors (VIF) measures how much the variance of the model coefficient increases due to the lack of orthogonality in
COD decreased by indirect oxidation of resorcinol with the production of redox reagents in the aqueous medium and $\mathrm{OH}$ radicals at $\mathrm{BDD}$ anode. The production of $\mathrm{S}_{2} \mathrm{O}_{8}^{2-}$ oxidizing ions in the presence of $\mathrm{Na}_{2} \mathrm{SO}_{4}$ electrolyte increased the COD removal efficiency as well. Most of the electrochemical processes are based on indirect oxidation because direct oxidation of organic pollutants is very slow at inert anodes due to reaction kinetics, limiting reactions, and mass transport limitations (Rajeshwar and 
TABLE 2 | Central composite design (CCD) and experimental results for the electrochemical oxidation of resorcinol in aqueous medium using BDD anode.

\begin{tabular}{|c|c|c|c|c|c|c|c|}
\hline Run & $x_{1}$ & $x_{2}$ & $x_{3}$ & $x_{4}$ & $\begin{array}{l}V_{m} \\
(V)\end{array}$ & $\begin{array}{l}\text { COD }_{0} \\
(\mathrm{mg} / \mathrm{L})\end{array}$ & $\begin{array}{c}\mathrm{COD}_{\mathrm{f}} \\
(\mathrm{mg} / \mathrm{L})\end{array}$ \\
\hline 1 & 0 & 0 & 0 & 0 & 8.9 & 637 & 83 \\
\hline 2 & 1 & -1 & -1 & 1 & 8.5 & 837 & 358 \\
\hline 3 & 0 & 0 & 0 & 2 & 8.6 & 639 & 179 \\
\hline 4 & 1 & -1 & 1 & -1 & 5.9 & 880 & 311 \\
\hline 5 & 0 & 0 & 0 & -2 & 11.4 & 665 & 155 \\
\hline 6 & -1 & -1 & 1 & 1 & 5.6 & 444 & 95 \\
\hline 7 & 2 & 0 & 0 & 0 & 8.5 & 1,068 & 167 \\
\hline 8 & -1 & -1 & -1 & -1 & 8.3 & 445 & 147 \\
\hline 9 & -1 & 1 & -1 & -1 & 13.9 & 461 & 119 \\
\hline 10 & 0 & 0 & 0 & 0 & 8.4 & 607 & 68 \\
\hline 11 & -1 & 1 & -1 & 1 & 13.3 & 433 & 51 \\
\hline 12 & 1 & 1 & 1 & 1 & 8.2 & 831 & 216 \\
\hline 13 & 0 & 0 & 0 & 0 & 7.8 & 658 & 85 \\
\hline 14 & 1 & 1 & -1 & -1 & 14.8 & 811 & 208 \\
\hline 15 & -1 & 1 & 1 & 1 & 7.3 & 434 & 74 \\
\hline 16 & -1 & 1 & 1 & -1 & 8.0 & 419 & 55 \\
\hline 17 & 1 & -1 & -1 & -1 & 10.8 & 891 & 259 \\
\hline 18 & 0 & 0 & 0 & 0 & 9.1 & 596 & 58 \\
\hline 19 & 0 & -2 & 0 & 0 & 6.5 & 602 & 352 \\
\hline 20 & 0 & 0 & 0 & 0 & 7.7 & 632 & 73 \\
\hline 21 & 0 & 0 & 2 & 0 & 7.2 & 631 & 93 \\
\hline 22 & -1 & -1 & -1 & 1 & 8.2 & 425 & 90 \\
\hline 23 & 1 & -1 & 1 & 1 & 5.9 & 825 & 266 \\
\hline 24 & 0 & 0 & -2 & 0 & 32.0 & 690 & 617 \\
\hline 25 & 1 & 1 & -1 & 1 & 15.0 & 788 & 101 \\
\hline 26 & -2 & 0 & 0 & 0 & 8.3 & 252 & 52 \\
\hline 27 & 0 & 0 & 0 & 0 & 7.9 & 600 & 256 \\
\hline 28 & -1 & -1 & 1 & -1 & 6.5 & 438 & 113 \\
\hline 29 & 1 & 1 & 1 & -1 & 9.5 & 813 & 116 \\
\hline 30 & 0 & 2 & 0 & 0 & 12.0 & 639 & 99 \\
\hline 31 & -1 & 0 & 0 & 0 & 8.2 & 440 & 64 \\
\hline 32 & 1 & 0 & 0 & 0 & 9.7 & 840 & 82 \\
\hline 33 & 0 & -1 & 0 & 0 & 6.4 & 628 & 193 \\
\hline 34 & 0 & 1 & 0 & 0 & 8.9 & 625 & 70 \\
\hline 35 & 0 & 0 & -1 & 0 & 12.0 & 634 & 256 \\
\hline 36 & 0 & 0 & 1 & 0 & 7.2 & 644 & 117 \\
\hline 37 & 0 & 0 & 0 & -1 & 7.4 & 695 & 120 \\
\hline 38 & 0 & 0 & 0 & 1 & 7.9 & 705 & 157 \\
\hline
\end{tabular}

Ibanez, 1997; Körbahti and Artut, 2010; Körbahti and Taşyürek, 2015).

In electrochemical processes, current density is an important parameter for controlling the reaction rate (Körbahti and Taşyürek, 2015). Increasing current density increases the electrochemical oxidation efficiency by increasing the conductivity, and in situ production of oxidizing redox reagents in the reaction medium and $\mathrm{OH}$ radicals at $\mathrm{BDD}$ anode (Körbahti and Taşyürek, 2015). However, gas evolution, electrolyte decomposition and side reactions result in a decrease
TABLE 3 | ANOVA results of the quadratic models of COD removal, mass transfer coefficient $(\mathrm{km}), \mathrm{J} / \mathrm{J}_{\lim }^{\circ}(\alpha)$ value and energy consumption for the electrochemical oxidation of resorcinol in aqueous medium using BDD anode.

\begin{tabular}{|c|c|c|c|c|c|}
\hline Source & $\begin{array}{l}\text { Sum of } \\
\text { squares }\end{array}$ & $\begin{array}{l}\text { Degrees of } \\
\text { freedom }\end{array}$ & $\begin{array}{c}\text { Mean } \\
\text { square }\end{array}$ & $F$-value & $P$-value \\
\hline \multicolumn{6}{|c|}{ COD REMOVAL $(s / n=6.775)$} \\
\hline Model & 5327.13 & 14 & 380.51 & 2.44 & 0.0278 \\
\hline Residual & 3581.35 & 23 & 155.71 & & \\
\hline Lack of fit & 2772.10 & 18 & 154.01 & 0.95 & 0.5811 \\
\hline Pure error & 809.25 & 5 & 161.85 & & \\
\hline \multicolumn{6}{|c|}{ MASS TRANSFER COEFFICIENT $(s / n=5.870)$} \\
\hline Model & 55.22 & 14 & 3.94 & 3.08 & 0.0082 \\
\hline Residual & 29.45 & 23 & 1.28 & & \\
\hline Lack of fit & 24.54 & 18 & 1.36 & 1.39 & 0.3837 \\
\hline Pure error & 4.91 & 5 & 0.98 & & \\
\hline \multicolumn{6}{|c|}{$\mathrm{J} / \mathrm{J}_{\lim }^{\circ}(\alpha)$ VALUE $(\mathrm{s} / n=7.952)$} \\
\hline Model & 225.66 & 13 & 17.36 & 2.35 & 0.0339 \\
\hline Residual & 177.41 & 24 & 7.39 & & \\
\hline Lack of fit & 176.91 & 19 & 9.31 & 92.01 & $<0.0001$ \\
\hline Pure error & 0.51 & 5 & 0.10 & & \\
\hline \multicolumn{6}{|c|}{ ENERGY CONSUMPTION $(s / n=12.951)$} \\
\hline Model & $1.251 \times 10^{5}$ & 14 & 8936.15 & 10.30 & $<0.0001$ \\
\hline Residual & 19948.90 & 23 & 867.34 & & \\
\hline Lack of fit & 19543.76 & 18 & 1085.76 & 13.40 & 0.0046 \\
\hline Pure error & 405.14 & 5 & 81.03 & & \\
\hline
\end{tabular}

in the removal yield and a loss of current efficiency during the mineralization of organic pollutants (Fernandes et al., 2004; Shen et al., 2006; Körbahti and Taşyürek, 2015). The electrochemical oxidation of organic compounds including phenols, chlorophenols, cresols, organic acids, naphthol, surfactants, herbicides, cyanides, pharmaceuticals, nitrophenols, polyhydroxybenzenes, polyacrylates, and textile dyes was studied in the literature (Bellagamba et al., 2002; Panizza et al., 2005; Weiss et al., 2007, 2008; Louhichi et al., 2008; González et al., 2011; Körbahti and Taşyürek, 2015), and it was reported that increasing current density increases the removal of organic pollutants, COD removal, and energy consumption.

In direct or indirect electrochemical oxidation side products and reaction intermediates generate before complete mineralization. This behavior was reported for the oxidation of organic compounds on BDD anodes that the oxidation occurs directly on the anode surface or indirectly in the aqueous medium very close to the anode surface mediated by hydroxyl radicals generated by the water oxidation (Cañizares et al., 2003, 2004; Nasr et al., 2005). The amount and the nature of the intermediates depend on the properties of the anodes and the process conditions (Comninellis and Chen, 2010). The main intermediates using BDD anodes were reported as maleic, oxalic, and formic acid which further oxidized at lower rates (Comninellis and Chen, 2010; Martínez-Huitle and Andrade, 2011; Körbahti and Taşyürek, 2015).

Comninellis and Chen (2010) reported that the mineralization reaction rate is independent of the organic compound in 


\section{A}
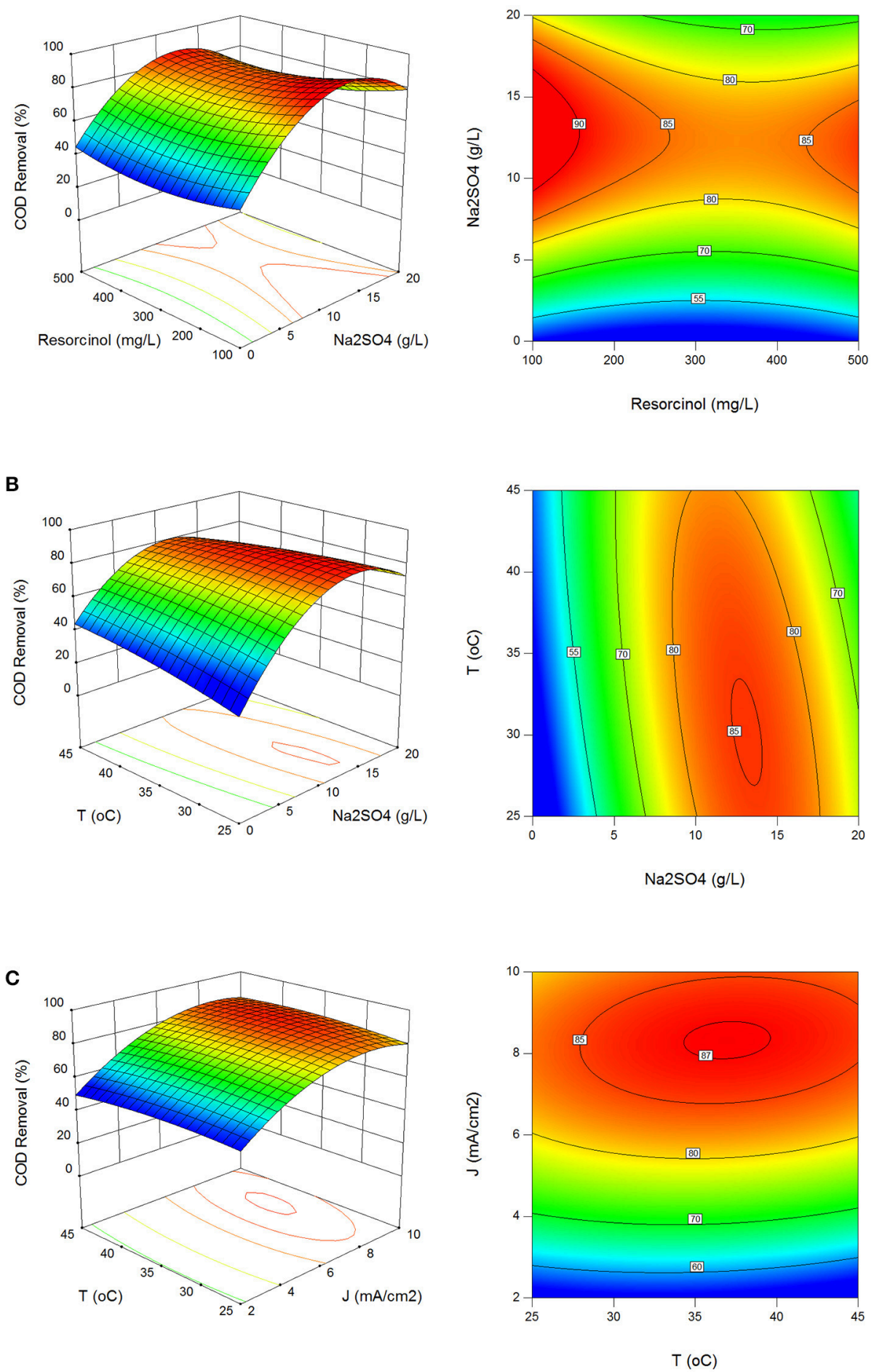

FIGURE 1 | Effect of process parameters on COD removal. (A) Effect of resorcinol concentration and $\mathrm{Na}_{2} \mathrm{SO}_{4}$ concentration $\left(\mathrm{J}=6 \mathrm{~mA} / \mathrm{cm}^{2}, T=35^{\circ} \mathrm{C}, t=120 \mathrm{~min}\right)$, (B) effect of $\mathrm{Na}_{2} \mathrm{SO}_{4}$ concentration and reaction temperature ( $\mathrm{C}_{0}=300 \mathrm{mg} / \mathrm{L}, J=6 \mathrm{~mA} / \mathrm{cm}^{2}, t=120 \mathrm{~min}$ ), (C) effect of reaction temperature and current density ( $\mathrm{C}_{\mathrm{O}}=300 \mathrm{mg} / \mathrm{L}, \mathrm{Na}_{2} \mathrm{SO}_{4}=10 \mathrm{~g} / \mathrm{L}, t=120 \mathrm{~min}$ ). 
the electrolyte. Therefore, mass transfer coefficient could be expressed in electrochemical reactors with the physical parameters of the system such as current density, electrode potential, electrochemical cell voltage, electrode length, electrolysis time, electrode area/electrolyte volume ratio, and electrolyte properties (Pletcher and Walsh, 1990; Rajeshwar and Ibanez, 1997). In Equation (10), mass transfer coefficient for stirred batch electrochemical reactor was expressed using mass balance over the reactor by Faraday's Law under mass transport control with convective diffusion (Pletcher and Walsh, 1990; Rajeshwar and Ibanez, 1997; Körbahti and Artut, 2010; Körbahti and Taşyürek, 2015).

$$
x_{S B E R}=1-\exp \left(-\frac{k_{m} A_{e}}{V_{R}} t\right)
$$

The effect of process parameters on mass transfer coefficient $\left(\mathrm{k}_{\mathrm{m}}\right)$ in surface and contour plots can be seen in Figures 2A-C. Mass transfer coefficients were evaluated between $0.33 \times 10^{-6}$ and 6.93 $\times 10^{-6} \mathrm{~m} / \mathrm{s}$ with standard deviation of $1.51 \times 10^{-6} \mathrm{~m} / \mathrm{s}$ which are consistent to those reported in the literature (Körbahti and Artut, 2010; Körbahti and Taşyürek, 2015). Higher than $5.5 \times 10^{-6} \mathrm{~m} / \mathrm{s}$ mass transfer coefficients were determined in the regions at 5.5$17.8 \mathrm{~g} / \mathrm{L} \mathrm{Na}_{2} \mathrm{SO}_{4}, 5.6-10 \mathrm{~mA} / \mathrm{cm}^{2}$ current density and $28-42^{\circ} \mathrm{C}$ reaction temperature in Figures 2A-C.

The limiting current density in the beginning of electrolysis $\left(\mathrm{J}_{\mathrm{lim}}^{\circ}\right)$ can be written under hydrodynamic conditions for the electrochemical mineralization of organic compounds in Equation (11) (Panizza and Cerisola, 2009; Comninellis and Chen, 2010; Martínez-Huitle and Andrade, 2011). The characteristic parameter, $\alpha$, can be defined for the electrochemical oxidation in Equation (12) (Comninellis and Chen, 2010):

$$
\begin{aligned}
J_{l i m}^{o} & =4 F k_{m} C O D_{o} \\
\alpha & =\frac{J}{J_{l i m}^{o}}
\end{aligned}
$$

$\alpha$ is constant under galvanostatic conditions and two different operating conditions can be defined (Panizza and Cerisola, 2009; Comninellis and Chen, 2010; Martínez-Huitle and Andrade, 2011):

(1) Electrochemical process is controlled by the applied current, COD decreases linearly with time and current efficiency is $100 \%(\alpha<1)$.

(2) Electrochemical process is controlled by the mass transport, secondary reactions involve and COD removal follows an exponential trend due to mass transport limitations results in instantaneous current efficiency (ICE) decrease $(\alpha>1)$.

In Figures 3A-C the effect of process parameters on $\mathrm{J} / \mathrm{J}_{\lim }^{\circ}(\alpha)$ values in surface and contour plots is shown. $J / J_{\text {lim }}^{\circ}$ values were obtained between 0.8 and 21.7 with standard deviation of 3.3. Electrolysis under current limited control results in the formation of many intermediates according to the electrolysis under mass transport control (Panizza and Cerisola, 2009; Comninellis and Chen, 2010; Martínez-Huitle and Andrade, 2011). Therefore, the process parameters were optimized for mass transport control in this study. It was found that the electrochemical oxidation of resorcinol using BDD anode should be operated for mass transport control region at initial resorcinol concentration $\leq 300$ $\mathrm{mg} / \mathrm{L}$, between 28 and $42^{\circ} \mathrm{C}$ reaction temperature and $4.5-10$ $\mathrm{mA} / \mathrm{cm}^{2}$ current density.

In electrolysis, electrical charge involves for the chemical changes in non-spontaneous oxidation and reduction reactions $(\Delta \mathrm{G}>0)$ and in most cases supplied electrical energy is larger than the Gibbs free energy change of the reactions. Therefore, energy consumption in electrochemical processes should be optimized for energy efficient processes. In the batch runs, energy consumption values were evaluated between 39.0 and 302.7 $\mathrm{kWh} / \mathrm{kg} \mathrm{COD}$ rith standard deviation of $62.6 \mathrm{kWh} / \mathrm{kg} \mathrm{COD}_{\mathrm{r}}$ using Equation (13).

$$
E C=\frac{i V_{m} \Delta t}{\left(C O D_{O}-C O D_{t}\right) V_{R}}
$$

Figures 4A-C show the effect of process parameters on energy consumption in surface and contour plots. Energy consumption decreased with the increase in resorcinol concentration and $\mathrm{Na}_{2} \mathrm{SO}_{4}$ concentration, and the decrease in the current density. The energy efficient reaction temperature was found between 28 and $42^{\circ} \mathrm{C}$.

Maximization of COD removal efficiency was preferred for the process optimization, and optimum process parameters were determined as $300 \mathrm{mg} / \mathrm{L}$ resorcinol concentration, $8 \mathrm{~mA} / \mathrm{cm}^{2}$ current density, $12 \mathrm{~g} / \mathrm{L} \mathrm{Na}_{2} \mathrm{SO}_{4}$ concentration and $34^{\circ} \mathrm{C}$ reaction temperature by analyzing Figures 1-4. In Figure 5, the shaded region shows the process efficiency for mass transfer controlled process at $>85 \%$ COD removal and $<150 \mathrm{kWh} / \mathrm{kg} \mathrm{COD}_{\mathrm{r}}$ energy consumption in $95 \%$ confidence interval. The specific batch run was conducted at response surface optimized conditions and the results are presented in Figure 6 and Table 4. It can be seen that the relationships developed between the responses and the process parameters in electrochemical oxidation of resorcinol using BDD anode were in very good agreement according to the relative error values lower than $\pm 5 \%$ as presented in Table 4 . In Figure 6, 100\% resorcinol removal and 89\% COD removal were obtained in $120 \mathrm{~min}$ reaction time. The initial rate of resorcinol oxidation was found higher than the COD removal. In Figure 6, the initial rates were calculated as 0.0257 and 0.0150 $\min ^{-1}$ for resorcinol oxidation and COD removal, respectively. These results confirmed that the electrochemical mineralization of resorcinol was successfully accomplished using BDD anode depending on the process conditions, however the formation of intermediates and by-products were further oxidized at much lower rate. Brillas and Martínez-Huitle (2015) also reported the formation of by-products such as aliphatic carboxylic acids in electrochemical treatment which are more difficult to oxidize with $\mathrm{BDD}\left({ }^{\bullet} \mathrm{OH}\right)$ than the aromatic pollutants.

Nasr et al. (2005) investigated the electrochemical oxidation of hydroquinone, resorcinol and catechol on boron-doped diamond anodes. The authors conducted the research at $13.5 \mathrm{mM}$ catechol, resorcinol or hydroquinone concentration, 3333.33 $\mathrm{mg} / \mathrm{L} \mathrm{Na}_{3} \mathrm{PO}_{4}$ electrolyte concentration, $\mathrm{pH} 2,30 \mathrm{~mA} / \mathrm{cm}^{2}$ current density and $25^{\circ} \mathrm{C}$ reaction temperature. Nasr et al. 



FIGURE 2 | Effect of process parameters on mass transfer coefficient $(\mathrm{km})$. (A) Effect of resorcinol concentration and $\mathrm{Na}_{2} \mathrm{SO}_{4}$ concentration $\left(\mathrm{J}=6 \mathrm{~mA} / \mathrm{cm}^{2}\right.$, $\left.T=35^{\circ} \mathrm{C}, t=120 \mathrm{~min}\right)$, (B) effect of $\mathrm{Na}_{2} \mathrm{SO}_{4}$ concentration and reaction temperature ( $\left.\mathrm{C}_{\mathrm{O}}=300 \mathrm{mg} / \mathrm{L}, J=6 \mathrm{~mA} / \mathrm{cm}^{2}, t=120 \mathrm{~min}\right)$, (C) effect of reaction temperature and current density $\left(\mathrm{C}_{\mathrm{O}}=300 \mathrm{mg} / \mathrm{L}, \mathrm{Na}_{2} \mathrm{SO}_{4}=10 \mathrm{~g} / \mathrm{L}, t=120 \mathrm{~min}\right)$.

(2005) reported that no aromatic intermediates were found during the treatment and aliphatic intermediates such as carboxylic acids were detected. The authors also observed that the oxidation of resorcinol leads to the formation of important amounts of glycolic and glyoxalic acids. The higher concentrations of $\mathrm{C}_{2}$ carboxylic acids indicate their lower 
A
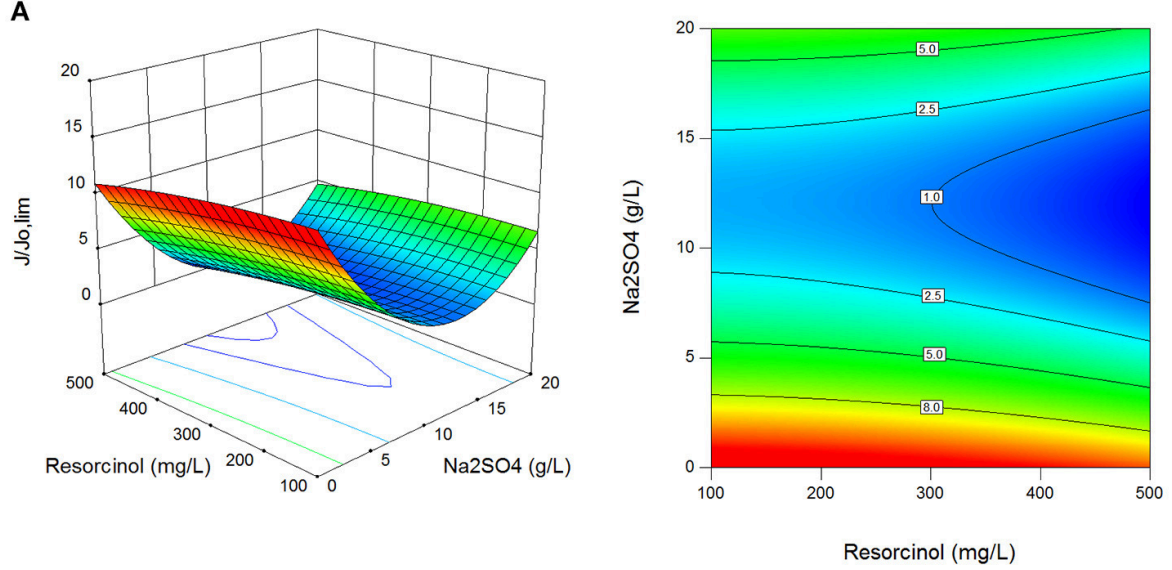

B
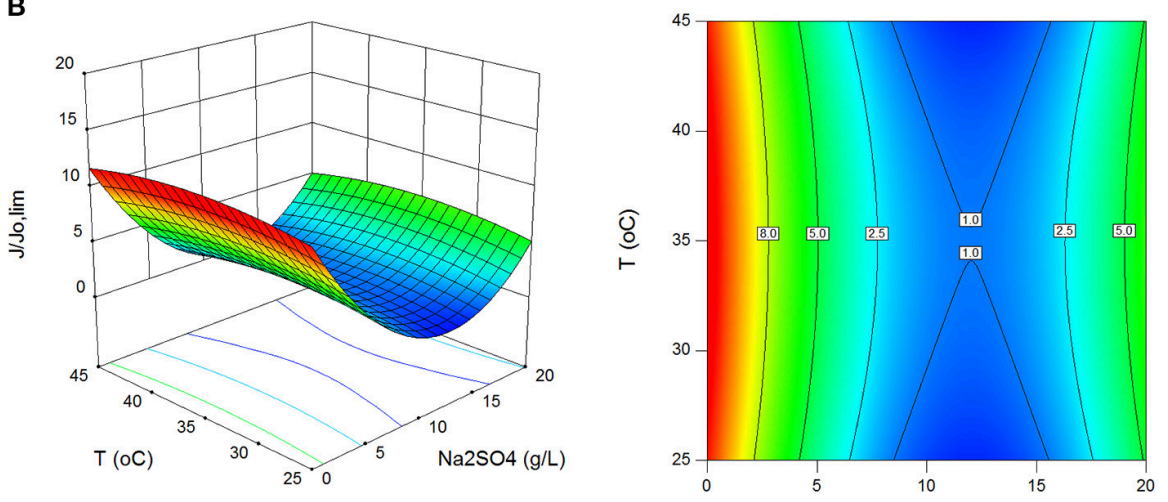

$\mathrm{Na} 2 \mathrm{SO} 4(\mathrm{~g} / \mathrm{L})$

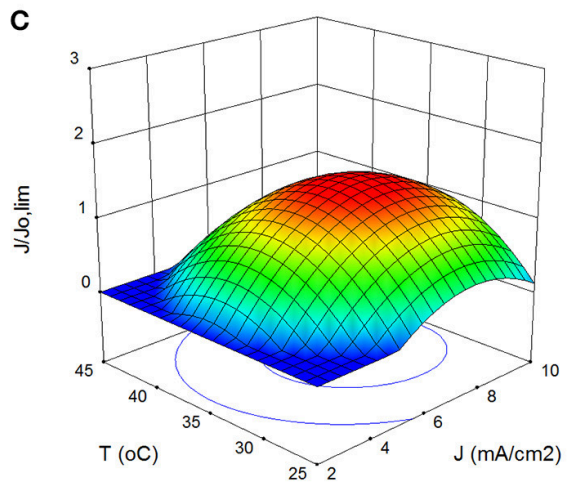

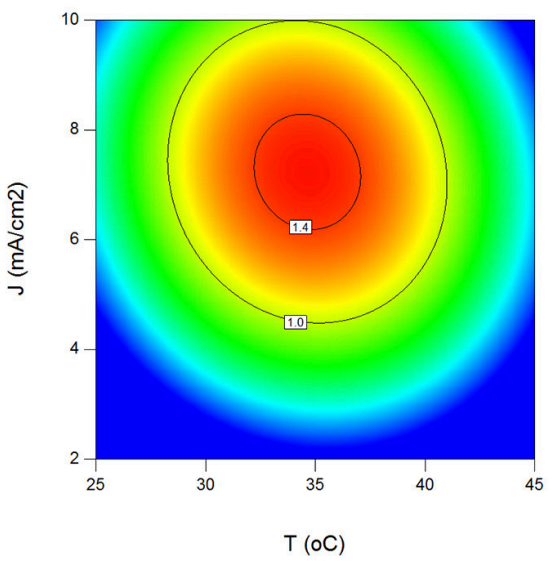

FIGURE 3 | Effect of process parameters on $\mathrm{J} / \mathrm{Jlim}_{\lim }^{\circ}(\alpha)$. (A) Effect of resorcinol concentration and $\mathrm{Na}_{2} \mathrm{SO}_{4}$ concentration $\left(\mathrm{J}=6 \mathrm{~mA} / \mathrm{cm}^{2}, T=35^{\circ} \mathrm{C}, t=120 \mathrm{~min}\right)$, (B) effect of $\mathrm{Na}_{2} \mathrm{SO}_{4}$ concentration and reaction temperature ( $\mathrm{C}_{0}=300 \mathrm{mg} / \mathrm{L}, J=6 \mathrm{~mA} / \mathrm{cm}^{2}, t=120 \mathrm{~min}$ ), (C) effect of reaction temperature and current density ( $\mathrm{C}_{\mathrm{O}}=300 \mathrm{mg} / \mathrm{L}, \mathrm{Na}_{2} \mathrm{SO}_{4}=10 \mathrm{~g} / \mathrm{L}, t=120 \mathrm{~min}$ ).

oxidazability in comparison with the initial aromatic compounds and with the $\mathrm{C}_{1}$ and $\mathrm{C}_{4}$ carboxylic acids (Nasr et al., 2005).
On the other hand, it is also possible to obtain mono-, di-, and tri- substituted chlorinated aromatic intermediates during the electrochemical oxidation of phenol in the presence of $\mathrm{NaCl}$ 

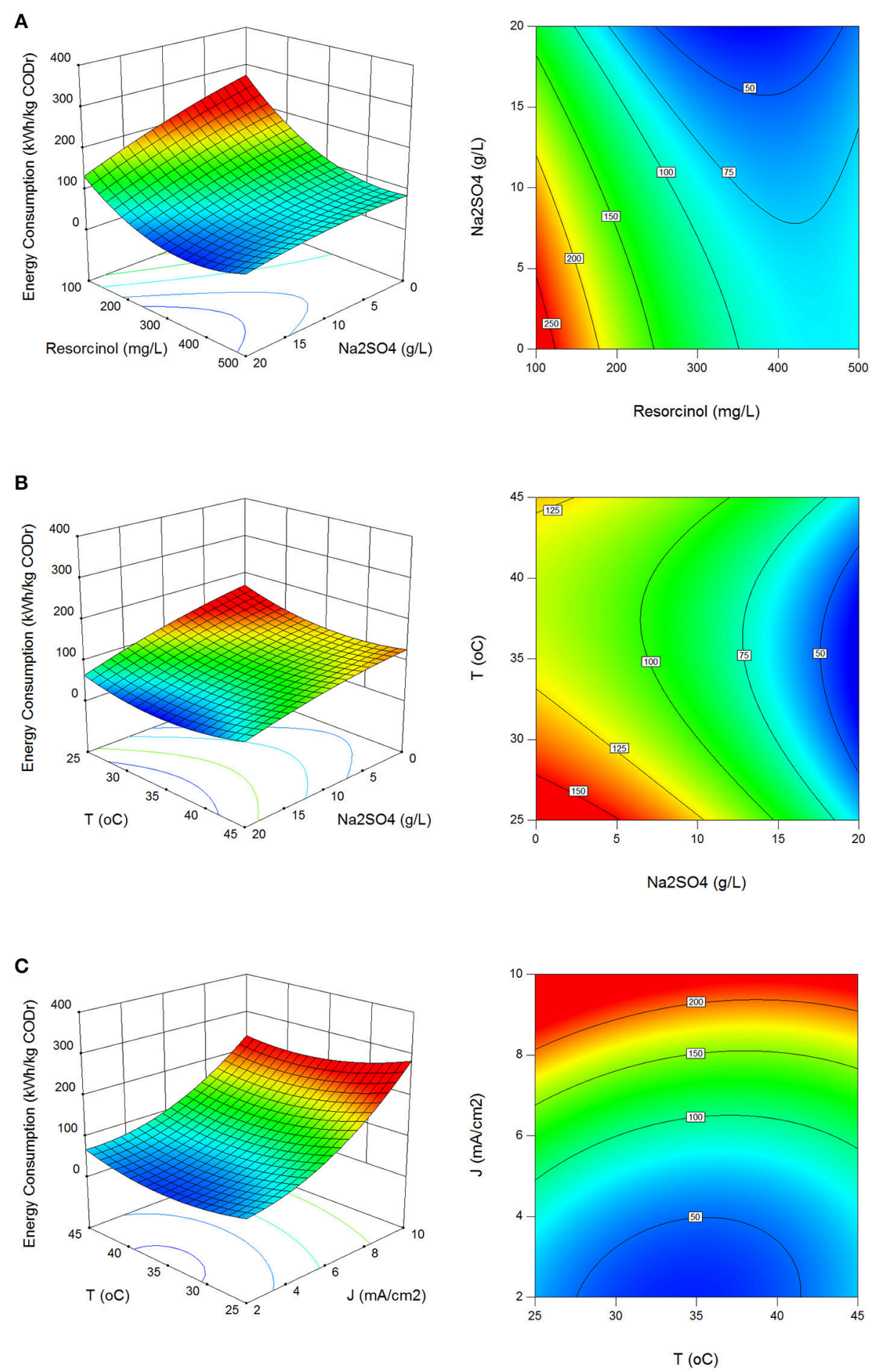

FIGURE 4 | Effect of process parameters on energy consumption. (A) Effect of resorcinol concentration and $\mathrm{Na}_{2} \mathrm{SO}_{4}$ concentration $\left(\mathrm{J}=6 \mathrm{~mA} / \mathrm{cm}^{2}, T=35^{\circ} \mathrm{C}\right.$, $t=120 \mathrm{~min}$ ), (B) effect of $\mathrm{Na}_{2} \mathrm{SO}_{4}$ concentration and reaction temperature ( $\left.\mathrm{C}_{\mathrm{O}}=300 \mathrm{mg} / \mathrm{L}, J=6 \mathrm{~mA} / \mathrm{cm}^{2}, t=120 \mathrm{~min}\right)$, (C) effect of reaction temperature and current density ( $\left.\mathrm{C}_{\mathrm{O}}=300 \mathrm{mg} / \mathrm{L}, \mathrm{Na}_{2} \mathrm{SO}_{4}=10 \mathrm{~g} / \mathrm{L}, t=120 \mathrm{~min}\right)$.

electrolyte (Comninellis and Nerini, 1995; Zareie et al., 2001; Körbahti et al., 2002). However, Comninellis and Chen (2010) indicated that electrochemical oxidation could be effectively used for the mineralization of toxic and biorefractory organic pollutants by using diamond film electrodes. Cañizares et al. (2006) also reported the results of the electrolysis at BDD of 

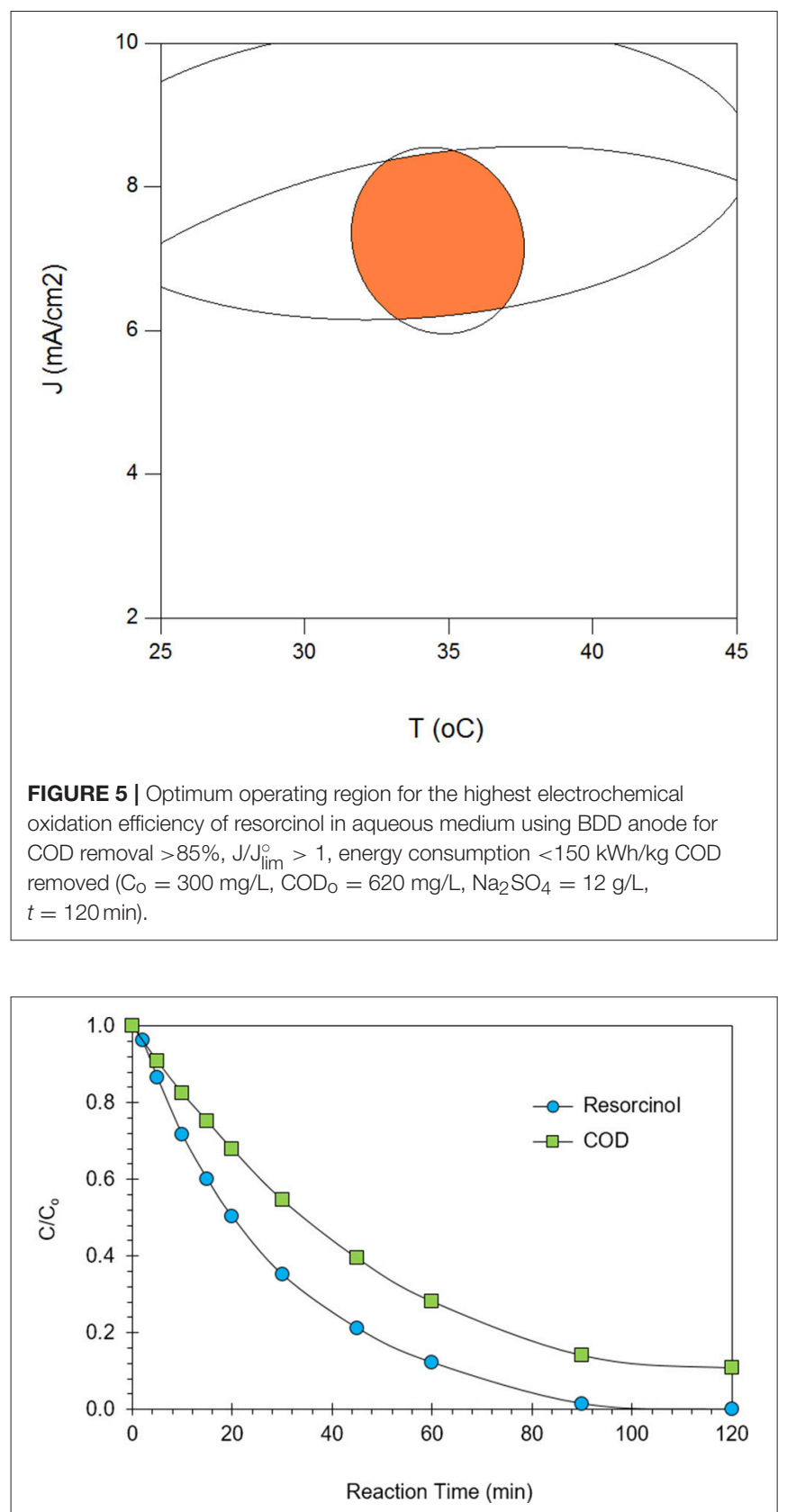

FIGURE 6 | Results of the batch run at response surface optimized conditions for the electrochemical oxidation of resorcinol in aqueous medium using BDD anode $\left(\mathrm{C}_{\mathrm{O}}=300 \mathrm{mg} / \mathrm{L}, \mathrm{COD}_{\circ}=620 \mathrm{mg} / \mathrm{L}, \mathrm{J}=8 \mathrm{~mA} / \mathrm{cm}^{2}, \mathrm{Na}_{2} \mathrm{SO}_{4}=12\right.$ $\left.\mathrm{g} / \mathrm{L}, T=34^{\circ} \mathrm{C}, t=120 \mathrm{~min}\right)$.

different substituted phenols showing a significant decrease of the toxicity during the treatment.

The other important issue is the formation of polymer films during the oxidation of dihydroxybenzenes in aqueous medium. It is known that the first stage in the oxidation of dihydroxybenzenes is the formation of a phenoxy radical that can be further oxidized to the quinone form or can couple with other radicals or dihydroxybenzenes to form polymers (Nasr
TABLE 4 | Results of the batch run at response surface optimized conditions for the electrochemical oxidation of resorcinol in aqueous medium using BDD anode $\left(\mathrm{C}_{\mathrm{o}}=300 \mathrm{mg} / \mathrm{L}, \mathrm{COD}_{\mathrm{O}}=620 \mathrm{mg} / \mathrm{L}, \mathrm{J}=8 \mathrm{~mA} / \mathrm{cm}^{2}, \mathrm{Na}_{2} \mathrm{SO}_{4}=12 \mathrm{~g} / \mathrm{L}, T=\right.$ $\left.34^{\circ} \mathrm{C}, t=120 \mathrm{~min}\right)$.

\begin{tabular}{|c|c|c|c|}
\hline Response & $\begin{array}{l}\text { Experimental } \\
\text { result }\end{array}$ & RSM model & Error $( \pm \%)$ \\
\hline $\mathrm{pH}$ & 4.6 & 4.4 & 4.3 \\
\hline COD removal (\%) & 89.0 & 88.5 & 0.6 \\
\hline $\mathrm{k}_{\mathrm{m}}(\mathrm{m} / \mathrm{s})$ & $6.58 \times 10^{-6}$ & $6.26 \times 10^{-6}$ & 4.9 \\
\hline$J_{\lim }^{O}\left(\mathrm{~mA} / \mathrm{cm}^{2}\right)$ & 4.9 & 4.7 & 4.1 \\
\hline$\alpha=\frac{J}{J_{\lim }^{\circ}}$ & $\begin{array}{l}\text { Mass transfer } \\
\text { controlled }\end{array}$ & $\begin{array}{l}\text { Mass transfer } \\
\text { controlled }\end{array}$ & - \\
\hline $\begin{array}{l}\text { Energy consumption } \\
\left(\mathrm{kWh} / \mathrm{kg} \mathrm{COD}_{\mathrm{r}}\right)\end{array}$ & 138.0 & 134.7 & 2.4 \\
\hline
\end{tabular}

et al., 2005). In our study, the polymer formation did not observe on the BDD surface and in the study of Nasr et al. (2005) as well. The authors indicated that the polymer formed must be easily removed by the hydroxyl radicals formed during the water decomposition (Nasr et al., 2005).

The electrochemical oxidation of resorcinol using BDD anode in aqueous medium was occurred irreversibly in a mass transport controlled process. BDD anode was proved for the electrochemical oxidation of resorcinol with its inert surface, good conductivity, corrosion resistance, and stability. Indirect oxidation was the dominating process as reported in the literature. Resorcinol and the reaction intermediates were oxidized mainly by the hydroxyl radicals produced by water oxidation on the BDD anode surface, and peroxodisulfate produced at high overpotential supplied by the BDD anode in the presence of $\mathrm{SO}_{4}^{2-}$ ions in the electrolyte (Serrano et al., 2002; Chen et al., 2004; Cañizares et al., 2005a; Nasr et al., 2005; Panizza and Cerisola, 2007; Comninellis et al., 2008; Weiss et al., 2008; Liu et al., 2009; Li et al., 2010; Sirés and Brillas, 2012; Davis et al., 2014). BDD anode could be used as a favorable electrode material for the total mineralization of organic pollutants that can be found in the wastewater.

\section{Reaction Kinetics for Electrochemical Oxidation of Resorcinol in Aqueous Medium Using BDD Anode}

Reaction kinetics for electrochemical oxidation of resorcinol in aqueous medium using BDD anode was investigated by the method of initial rates in a batch electrochemical reactor at response surface optimized conditions. The overall electrochemical oxidation rate of pollutants in a batch electrochemical reactor can be expressed based on COD concentration as shown in Equation (14) (Chiang et al., 1997; Lin et al., 1998; Szpyrkowicz et al., 2001a,b, 2005; Körbahti and Artut, 2010).

$$
\begin{aligned}
-\frac{d C_{C O D}}{d t} & =k C_{C O D}^{n} \\
\ln \left(-\frac{d C_{C O D}}{d t}\right) & =\ln (k)+n \cdot \ln \left(C_{C O D}\right)
\end{aligned}
$$


Equation (14) can be linearized into Equation (15) for the evaluation of reaction order $(n)$ and reaction rate constant $(k)$ from batch reactor data. In Figure 7 , the reaction order and reaction rate constant at $34^{\circ} \mathrm{C}$ optimum reaction temperature were determined with linear regression $\left(R^{2}=0.96\right)$ as 1 and $0.0145 \mathrm{~min}^{-1}$, respectively. Liu et al. (2009) investigated the electrochemical degradation of chlorobenzene on borondoped diamond and platinum electrodes, and compared the degradation kinetics on these electrodes. The authors reported that the decay of chlorobenzene on BDD and Pt electrodes were both pseudo-first-order reactions, and the reaction rate constant on BDD was calculated as $0.0118 \mathrm{~min}^{-1}$ which was higher than on the Pt electrode (Liu et al., 2009). It was also reported in the literature that first-order reaction kinetics for COD removal in the degradation of organic compounds is appropriate for the entire concentration range and several studies were reasonably well fitted to this kinetic model in electrochemical wastewater treatment processes depending on the process conditions (Xiong et al., 2001; Rajkumar and Palanivelu, 2004; Szpyrkowicz et al., 2005; Kong et al., 2006; Panizza and Cerisola, 2006, 2009; Koparal et al., 2007; Brillas et al., 2009; Radha et al., 2009; Körbahti and Artut, 2010; Brillas and Martínez-Huitle, 2015).

The reaction rate constant $(k)$ can be defined with Arrhenius equation (Equation 16) and that can be linearized into Equation (17) when overall reaction rate is expressed with Equation (14).

$$
\begin{aligned}
k & =A \cdot \exp \left(-\frac{E_{a}}{R T}\right) \\
\ln (k) & =\ln (A)-\frac{E_{a}}{R T}
\end{aligned}
$$

In Figure 8, the reaction rate constant $(k)$ was calculated between 25 and $45^{\circ} \mathrm{C}$ reaction temperatures and plotted vs. $1 / \mathrm{T}$ with linear regression $\left(R^{2}=0.97\right)$. The activation energy $\left(E_{a}\right)$ and the frequency factor $(A)$ were evaluated at $300 \mathrm{mg} / \mathrm{L}$ optimum resorcinol concentration as $5.32 \mathrm{~kJ} / \mathrm{mol}$ and 0.1169 $\mathrm{min}^{-1}$, respectively. The activation energy depends on the nature of the reaction and fast reactions generally have small $E_{a}$ values. It is known that the activation energy for a diffusioncontrolled homogeneous reaction is $<40 \mathrm{~kJ} / \mathrm{mol}$ (Samet et al., 2006; Körbahti and Artut, 2010). Therefore, the electrochemical oxidation of resorcinol in aqueous medium using BDD anode was supported a diffusion-controlled reaction.

\section{CONCLUDING REMARKS}

In this study, the electrochemical oxidation of resorcinol in aqueous medium using boron-doped diamond (BDD) anode was investigated in a batch electrochemical reactor. The following conclusions were drawn from the study:

- The effect of process parameters on COD removal, mass transfer coefficient $\left(\mathrm{k}_{\mathrm{m}}\right), \mathrm{J} / \mathrm{J}_{\lim }^{\circ}$ values $(\alpha)$, and energy consumption were evaluated. Depending on the process conditions.

- COD removal was obtained between 10.6 and $90.3 \%$ in 120 min reaction time.

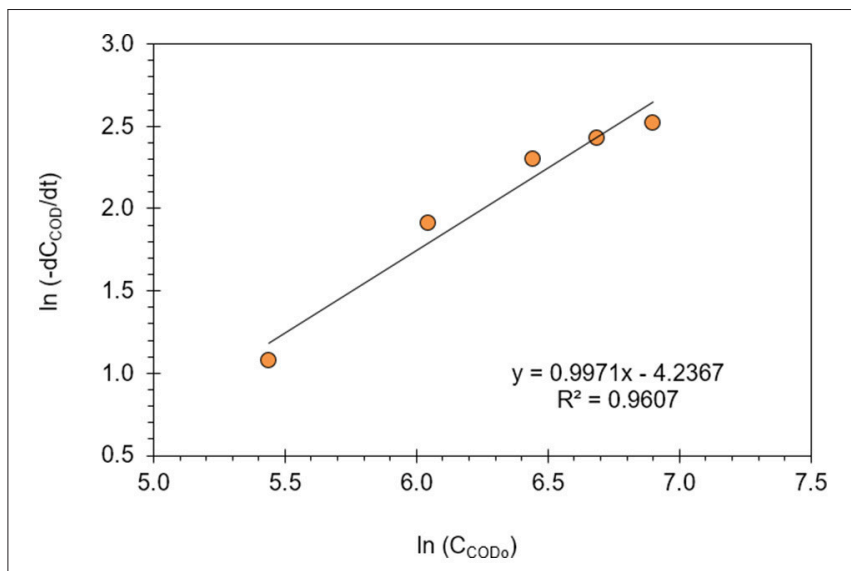

FIGURE 7 | Reaction order $(n)$ and reaction rate constant $(k)$ of electrochemical oxidation of resorcinol in aqueous medium using BDD anode $\left(\mathrm{J}=8 \mathrm{~mA} / \mathrm{cm}^{2}, \mathrm{Na}_{2} \mathrm{SO}_{4}=12 \mathrm{~g} / \mathrm{L}, T=34^{\circ} \mathrm{C}\right)$.

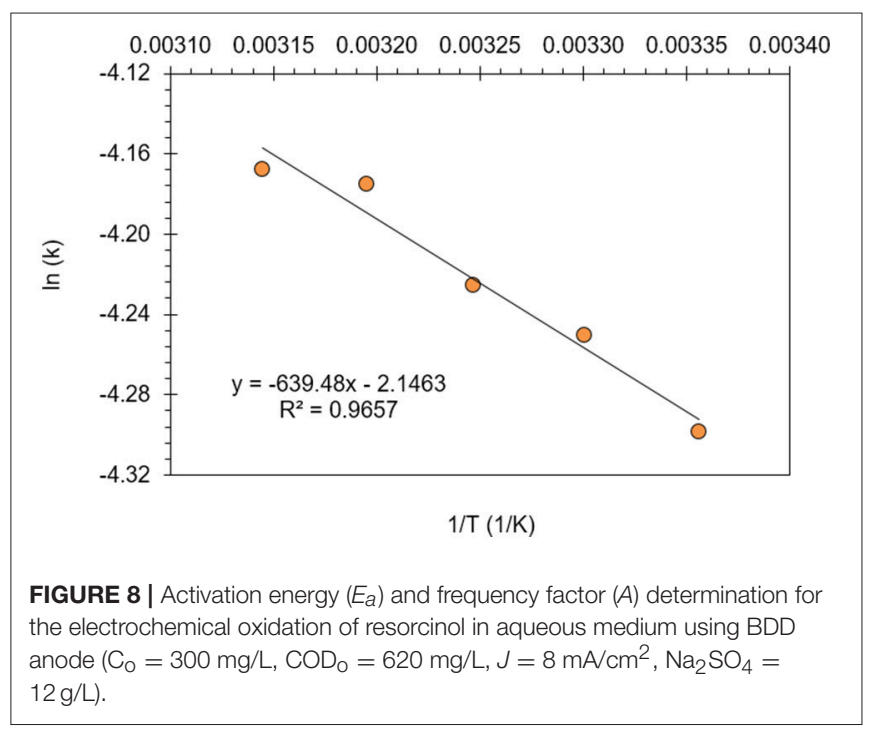

- Mass transfer coefficients $\left(\mathrm{k}_{\mathrm{m}}\right)$ were calculated between 0.33 $\times 10^{-6}$ and $6.93 \times 10^{-6} \mathrm{~m} / \mathrm{s}$.

- Energy consumption values were evaluated between 39.0 and $302.7 \mathrm{kWh} / \mathrm{kg} \mathrm{COD}_{\mathrm{r}}$.

- $\mathrm{J} / \mathrm{J}_{\lim }^{\circ}$ values $(\alpha)$ were calculated between 0.8 and 21.7 and the process was optimized for the operation in mass transport control region $(\alpha>1)$ using RSM.

- Optimum process parameters were determined as $\mathrm{C}_{\mathrm{o}}=300$ $\mathrm{mg} / \mathrm{L}, J=8 \mathrm{~mA} / \mathrm{cm}^{2}, \mathrm{Na}_{2} \mathrm{SO}_{4}=12 \mathrm{~g} / \mathrm{L}, T=34^{\circ} \mathrm{C}$ for mass transfer controlled process at $>85 \%$ COD removal and $<150$ $\mathrm{kWh} / \mathrm{kg} \mathrm{COD}_{\mathrm{r}}$ energy consumption.

- One hundred percent of resorcinol removal and 89\% COD removal were obtained at response surface optimized conditions in 120 min reaction time.

- Initial rate of resorcinol oxidation was found higher than the COD removal. 
- Electrochemical oxidation of resorcinol in aqueous medium using BDD anode was determined as first order reaction based on COD concentration with the activation energy of $5.32 \mathrm{~kJ} / \mathrm{mol}$ that was supported a diffusion-controlled reaction.

- The relationships developed between the responses and the process parameters were in very good agreement according to the relative error values $< \pm 5 \%$.

The experimental results of this study showed the feasibility of using boron-doped diamond (BDD) anode in electrochemical oxidation of phenolic effluents that can be found in domestic and industrial wastewater.

\section{REFERENCES}

Bellagamba, R., Michaud, P., Comninellis, C. H., and Vatistas, N. (2002). Electrocombustion of polyacrylates with boron-doped diamond anodes. Electrochem. Commun. 4, 171-176. doi: 10.1016/S1388-2481(01)00302-2

Brillas, E., and Martínez-Huitle, C. A. (2015). Decontamination of wastewaters containing synthetic organic dyes by electrochemical methods. an updated review. Appl. Catal. B 166-167, 603-643. doi: 10.1016/j.apcatb.2014.11.016

Brillas, E., Sirés, I., and Oturan, M. A. (2009). Electro-fenton process and related electrochemical technologies based on fenton's reaction chemistry. Chem. Rev. 109, 6570-6631. doi: 10.1021/cr900136g

Cañizares, P., Larrondo, F., Lobato, J., Rodrigo, M. A., and Sáez, C. (2005a). Electrochemical synthesis of peroxodiphosphate using boron-doped diamond anodes. J. Electrochem. Soc. 152, D191-D196. doi: 10.1149/1.2039936

Cañizares, P., Lobato, J., Paz, R., Rodrigo, M. A., and Sáez, C. (2005b). Electrochemical oxidation of phenolic wastes with boron-doped diamond anodes. Water Res. 39, 2687-2703. doi: 10.1021/acs.jpca.7b02630

Cañizares, P., Sáez, C., Lobato, J., and Rodrigo, M. A. (2003). Electrochemical oxidation of aqueous carboxylic acid wastes using diamond thin-film electrodes. Ind. Eng. Chem. Res. 42, 956-962. doi: 10.1021/ie02059

Cañizares, P., Sáez, C., Lobato, J., and Rodrigo, M. A. (2004). Electrochemical treatment of 4-nitrophenol-containing aqueous wastes using boron-doped diamond anodes. Ind. Eng. Chem. Res. 43, 1944-1951. doi: 10.1021/ie034025t

Cañizares, P., Sáez, C., Lobato, J., and Rodrigo, M. A. (2006). Detoxification of synthetic industrial wastewaters using electrochemical oxidation with boron-doped diamond anodes. J. Chem. Technol. Biotechnol. 81, 352-358. doi: $10.1002 /$ jctb.1402

Chen, X., Chen, G., Gao, F., and Yue, P. L. (2004). High-performance Ti/BDD electrodes for pollutant oxidation. Environ. Sci. Technol. 37, 5021-5026. doi: $10.1021 / \mathrm{es} 026443 \mathrm{f}$

Chiang, L.-C., Chang, J.-E., and Tseng, S.-C. (1997). Electrochemical oxidation pretreatment of refractory organic pollutants. Water Sci. Technol. 36, 123-130. doi: $10.1016 /$ S0273-1223(97)00378-8

Comninellis, C. H., and Chen, G. (eds). (2010). Electrochemistry for the Environment. New York, NY: Springer.

Comninellis, C. H., and Nerini, A. (1995). Anodic oxidation of phenol in the presence of $\mathrm{NaCl}$ for wastewater treatment. J. Appl. Electrochem. 25, 23-28. doi: 10.1007/BF00251260

Comninellis, C. H., Kapalka, A., Malato, S., Parsons, S. A., Poulios, I., and Mantzavinos, D. (2008). Advanced oxidation processes for water treatment: advances and trends for R\&D. J. Chem. Technol. Biotechnol. 83, 769-776. doi: $10.1002 /$ jctb. 1873

Davis, J., Baygents, J. C., and Farrell, J. (2014). Understanding persulfate production at boron doped diamond film anodes. Electrochim. Acta 150, 68-74. doi: $10.1016 /$ j.electacta.2014.10.104

Duan, X., Ma, F., Yuan, Z., Chang, L., and Jin, X. (2013). Electrochemical degradation of phenol in aqueous solution using $\mathrm{PbO}_{2}$ anode. J. Taiwan Inst. Chem. Eng. 44, 95-102. doi: 10.1016/j.jtice.2012.08.009

\section{AUTHOR CONTRIBUTIONS}

PD conducted the literature review, performed the experiments, analyzed the results, and prepared the draft manuscript. BK guided in design of experiments, response surface methodology, process optimization and reaction kinetics, and revised the manuscript. BK is the supervisor of this research.

\section{ACKNOWLEDGMENTS}

This project was supported by Mersin University Scientific Research Projects Center (MEÜ BAP) with Grant No. BAP-FBE KM (PD) 2011-2 YL.

Fernandes, A., Morão, A., Magrinho, A., Lopes, A., and Gonçalves, I. (2004). Electrochemical degradation of C. I. Acid Orange 7. Dyes Pigments 61, 287-296. doi: 10.1016/j.dyepig.2003.11.008

González, T., Domínguez, J. R., Palo, P., Sánchez-Martín, J., and Cuerda-Correa, E. M. (2011). Development and optimization of the BDD-electrochemical oxidation of the antibiotic trimethoprim in aqueous solution. Desalination 280, 197-202. doi: 10.1016/j.desal.2011.07.012

Hahn, S., Kielhorn, J., Koppenhöfer, J., Wibbertmann, A., and Mangelsdorf, I. (2006). Concise International Chemical Assessment Document 71. Geneva: World Health Organization (WHO).

Jarrah, N., and Mu'azu, N. D. (2016). Simultaneous electro-oxidation of phenol, $\mathrm{CN}^{-}, \mathrm{S}^{2-}$ and $\mathrm{NH}_{4}^{+}$in synthetic wastewater using boron doped diamond anode. J. Environ. Chem. Eng. 4, 2656-2664. doi: 10.1016/j.jece.2016.04.011

Jin, P., Chang, R., Liu, D., Zhao, K., Zhang, L., and Ouyang, Y. (2014). Phenol degradation in an electrochemical system with $\mathrm{TiO}_{2}$ /activated carbon fiber as electrode. J. Environ. Chem. Eng. 2, 1040-1047. doi: 10.1016/j.jece.2014.03.023

Kong, W., Wang, B., Ma, H., and Gu, L. (2006). Electrochemical treatment of anionic surfactants in synthetic wastewater with three-dimensional electrodes. J. Hazard. Mater. 137, 1532-1537. doi: 10.1016/j.jhazmat.2006.04.037

Koparal, A. S., Yavuz, Y., Gürel, C., and Ögütveren, Ü. B. (2007). Electrochemical degradation and toxicity reduction of C.I. Basic Red 29 solution and textile wastewater by using diamond anode. J. Hazard. Mater. 145, 100-108. doi: 10.1016/j.jhazmat.2006.10.090

Körbahti, B. K., and Artut, K. (2010). Electrochemical oil/water demulsification and purification of bilge water using $\mathrm{Pt} / \mathrm{Ir}$ electrodes. Desalination 258, 219-228. doi: 10.1016/j.desal.2010.03.008

Körbahti, B. K., Salih, B., and Tanyolaç, A. (2002). Electrochemical conversion of phenolic wastewater on carbon electrodes in the presence of $\mathrm{NaCl}$. J. Chem. Technol. Biotechnol. 77, 70-76. doi: 10.1002/jctb.524

Körbahti, B. K., and Taşyürek, S. (2015). Electrochemical oxidation of ampicillin antibiotic at boron-doped diamond electrodes and process optimization using response surface methodology. Environ. Sci. Pollut. Res. 22, 3265-3278. doi: 10.1007/s11356-014-3101-7

Li, H., Chen, Y., Zhang, Y., Han, W., Sun, X., Li, J., et al. (2013). Preparation of $\mathrm{Ti} / \mathrm{PbO}_{2}-\mathrm{Sn}$ anodes for electrochemical degradation of phenol. J. Electroanal. Chem. 689, 193-200. doi: 10.1016/j.jelechem.2012.11.035

Li, H., Zhu, X., and Ni, J. (2010). Inactivation of Escherichia coli in $\mathrm{Na}_{2} \mathrm{SO}_{4}$ electrolyte using boron-doped diamond anode. Electrochim. Acta 56, 448-453. doi: 10.1016/j.electacta.2010.08.055

Lin, S. H., Shyu, C. T., and Sun, M. C. (1998). Saline wastewater treatment by electrochemical method. Water Res. 32, 1059-1066. doi: 10.1016/S00431354(97)00327-8

Liu, L., Zhao, G., Wu, M., Lei, Y., and Geng, R. (2009). Electrochemical degradation of chlorobenzene on boron-doped diamond and platinum electrodes. J. Hazard. Mater. 168, 179-186. doi: 10.1016/j.jhazmat.2009.02.004

Louhichi, B., Ahmadi, M. F., Bensalah, N., Gadri, A., and Rodrigo, M. A. (2008). Electrochemical degradation of an anionic surfactant on boron-doped diamond anodes. J. Hazard. Mater. 158, 430-437. doi: 10.1016/j.jhazmat.2008.01.093 
Lynch, B. S., Delzell, E. S., and Bechtel, D. H. (2002). Toxicology review and risk assessment of Resorcinol: Thyroid effects. Regul. Toxicol. Pharmacol. 36, 198-210. doi: 10.1006/rtph.2002.1585

Martínez-Huitle, C. A., and Andrade, L. S. (2011). Electrocatalysis in wastewater treatment: recent mechanism advances. Quim. Nova 34, 850-858. doi: $10.1590 /$ S0100-40422011000500021

Montgomery, D. C. (2009). Design and Analysis of Experiments. Hoboken, NJ: John Wiley \& Sons.

Mu'azu, N. D., Al-Yahya, M., Al-Haj-Alib, A. M., and Abdel-Magid, I. M. (2016). Specific energy consumption reduction during pulsed electrochemical oxidation of phenol using graphite electrodes. J. Environ. Chem. Eng. 4, 2477-2486. doi: 10.1016/j.jece.2016.04.026

Myers, R. H., Montgomery, D. C., and Andersen-Cook, C. M. (2009). Response Surface Methodology: Process and Product Optimization using Designed Experiments. Hoboken, NJ: John Wiley \& Sons.

Nair, A. T., Makwana, A. R., and Ahammed, M. M. (2014). The use of response surface methodology for modelling and analysis of water and wastewater treatment processes: a review. Water Sci. Technol. 69, 464-478. doi: $10.2166 /$ wst. 2013.733

Nasr, B., Abdellatif, G., Cañizares, P., Sáez, C., Lobato, J., and Rodrigo, M. A. (2005). Electrochemical oxidation of hydroquinone, resorcinol, and catechol on boron-doped diamond anodes. Environ. Sci. Technol. 39, 7234-7239. doi: $10.1021 /$ es 0500660

National Toxicology Program (1992). Toxicology and Carcinogenesis Studies of Resorcinol (CAS No. 108-46-3) in F344/N rats and B6C3F1 Mice (Gavage Studies). NTP Technical Report Series, No. 403. NTP, Research Triangle Park, USA.

Panizza, M., and Cerisola, G. (2006). Olive mill wastewater treatment by anodic oxidation with parallel plate electrodes. Water Res. 40, 1179-1184. doi: 10.1016/j.watres.2006.01.020

Panizza, M., and Cerisola, G. (2007). Electrocatalytic materials for the electrochemical oxidation of synthetic dyes. Appl. Catal. B 75, 95-101. doi: 10.1016/j.apcatb.2007.04.001

Panizza, M., and Cerisola, G. (2009). Direct and mediated anodic oxidation of organic pollutants. Chem. Rev. 109, 6541-6569. doi: 10.1021/cr9001319

Panizza, M., Delucchi, M., and Cerisola, G. (2005). Electrochemical degradation of anionic surfactants. J. Appl. Electrochem. 35, 357-361. doi: 10.1007/s10800-005-0793-x

Pletcher, D., and Walsh, F. C. (1990). Industrial Electrochemistry. New York, NY: Chapman and Hall.

Radha, K. V., Sridevi, V., and Kalaivani, K. (2009). Electrochemical oxidation for the treatment of textile industry wastewater. Bioresour. Technol. 100, 987-990. doi: 10.1016/j.biortech.2008.06.048

Rajeshwar, K., and Ibanez, J. G. (1997). Environmental Electrochemistry. San Diego, CA: Academic Press.

Rajkumar, D., and Palanivelu, K. (2004). Electrochemical treatment of industrial wastewater. J. Hazard. Mater. 113, 123-129. doi: 10.1016/j.jhazmat.2004.05.039

Samet, Y., Chaabane Elaoud, S., Ammar, S., and Abdelhedi, R. (2006). Electrochemical degradation of 4-chloroguaiacol for wastewater treatment using $\mathrm{PbO}_{2}$ anodes. J. Hazard. Mater. 138, 614-619. doi: 10.1016/j.jhazmat. 2006.05.100
Serrano, K., Michaud, P. A., Comninellis, C, and Savall, A. (2002). Electrochemical preparation of peroxodisulfuric acid using boron doped diamond thin film electrodes. Electrochim. Acta 48, 431-436. doi: 10.1016/S0013-4686(02) 00688-6

Shen, Z. M., Wu, D., Yang, J., Yuan, T., Wang, W. H., and Jia, J. P. (2006). Methods to improve electrochemical treatment effect of dye wastewater. J. Hazard. Mater. 131, 90-97. doi: 10.1016/j.jhazmat.2005.09.010

Sirés, I., and Brillas, E. (2012). Remediation of water pollution caused by pharmaceutical residues based on electrochemical separation and degradation technologies. Environ. Int. 40, 212-229. doi: 10.1016/j.envint.2011.07.012

Skowroñ, J., and Zapór, L. (2004). Cytotoxicity of Resorcinol under shortand long-term exposure in vitro. Int. J. Occup. Saf. Ergon. 10, 147-156. doi: 10.1080/10803548.2004.11076603

Szpyrkowicz, L., Juzzolino, C., Daniele, S., and de Faveri, M. D. (2001a). Electrochemical destruction of thiourea dioxide in an undivided parallel plate electrodes batch reactor. Catal. Today 66, 519-527. doi: 10.1016/S09205861(00)00624-6

Szpyrkowicz, L., Juzzolino, C., and Kaul, S. N. (2001b). A comparative study on oxidation of disperse dyes by electrochemical process, ozone, hypochlorite and Fenton reagent. Water Res. 35, 2129-2136. doi: 10.1016/ S0043-1354(00)00487-5

Szpyrkowicz, L., Kaul, S. N., Neti, R. N., and Satyanarayan, S. (2005). Influence of anode material on electrochemical oxidation for the treatment of tannery wastewater. Water Res. 39, 1601-1613. doi: 10.1016/j.watres.2005.01.016

Weiss, E., Groenen-Serrano, K., and Savall, A. (2007). Electrochemical mineralization of sodium dodecylbenzenesulfonate at boron doped diamond anodes. J. Appl. Electrochem. 37, 1337-1344. doi: 10.1007/s10800-0079367-4

Weiss, E., Groenen-Serrano, K., and Savall, A. (2008). A comparison of electrochemical degradation of phenol on boron doped diamond and lead dioxide anodes. J. Appl. Electrochem. 38, 329-337. doi: 10.1007/s10800007-9442-x

Xiong, Y. A., Strunk, P. J., Xia, H., Zhu, X., and Karlsson, H. T. (2001). Treatment of dye wastewater containing acid orange II using a cell with three-phase three-dimensional electrode. Water Res. 35, 4226-4230. doi: 10.1016/S0043-1354(01)00147-6

Zareie, M. H., Körbahti, B. K., and Tanyolaç, A. (2001). Non-passivating polymeric structures in electrochemical conversion of phenol in the presence of $\mathrm{NaCl}$, J. Hazard. Mater. 87, 199-212. doi: 10.1016/S0304-3894(01) 00278-3

Conflict of Interest Statement: The authors declare that the research was conducted in the absence of any commercial or financial relationships that could be construed as a potential conflict of interest.

Copyright (C) 2017 Körbahti and Demirbüken. This is an open-access article distributed under the terms of the Creative Commons Attribution License (CC BY). The use, distribution or reproduction in other forums is permitted, provided the original author(s) or licensor are credited and that the original publication in this journal is cited, in accordance with accepted academic practice. No use, distribution or reproduction is permitted which does not comply with these terms. 